\title{
The role of insulin and thyroid hormones in the regulation of muscle growth and protein turnover in response to dietary protein in the rat
}

\author{
BY M. M. JEPSON, P. C. BATES AND D. J. MILLWARD* \\ Nutrition Research Unit, London School of Hygiene and Tropical Medicine, \\ St Pancras Hospital, 4 St Pancras Way, London NW1 2PE
}

(Received 27 July 1987 - Accepted 18 November 1987)

1. We have investigated the relations between changes in plasma insulin and 3,5,3'-triiodothyronine $\left(\mathrm{T}_{3}\right)$, and muscle growth and protein turnover in the rat in response to diets of varying protein concentrations.

2. Young rats were fed ad lib. on a control $(180 \mathrm{~g}$ casein $/ \mathrm{kg})$ diet or low-protein diets containing 80,45 and $0 \mathrm{~g}$ casein $/ \mathrm{kg}$ in four separate experiments. Measurements were made of food intakes, muscle and body-weight growth rates, muscle protein turnover in vivo, plasma insulin, and plasma free and total $\mathbf{T}_{3}$.

3. The food intakes of the 80 and $45 \mathrm{~g}$ casein $/ \mathrm{kg}$ diet groups were variable, with the $80 \mathrm{~g}$ casein $/ \mathrm{kg}$ diet group consuming either the same or more than the controls, and the $45 \mathrm{~g}$ casein $/ \mathrm{kg}$ diet group consuming less or more than the controls. Body-weight and skeletal-muscle growth rates varied with the protein but not energy intakes, which in turn reflected both dietary composition and the food intake, with the hyperphagic $80 \mathrm{~g}$ casein $/ \mathrm{kg}$ diet group of rats growing almost normally and the $0 \mathrm{~g}$ casein $/ \mathrm{kg}$ diet group losing body-weight and muscle mass.

4. Changes in rates of muscle growth were accompanied by parallel changes in rates of protein synthesis and degradation, as well as parallel changes in concentrations of plasma insulin and free $T_{3}$, to the extent that all these variables were highly correlated with each other.

5. Partial correlation analysis was used to separate interactions between variables. This indicated that dietary energy had no identifiable influence on muscle growth. In contrast dietary protein appeared to stimulate muscle growth directly by increasing muscle RNA content and inhibiting proteolysis, as well as increasing insulin and free $\mathrm{T}_{3}$ levels. Insulin and free $\mathrm{T}_{3}$ stimulated each other as well as muscle protein turnover; insulin stimulating the RNA activity particularly at low insulin levels, free $T_{3}$ stimulating the RNA content and both hormones stimulating proteolysis.

6. These apparent relations are shown to be consistent in the main part with previous studies of the mechanism of action of insulin and $T_{3}$, but the possibility cannot be discounted that other anabolic hormones not measured in these studies are involved, particularly in the apparent direct influence of dietary protein on muscle.

The present paper is concerned with the way in which dietary protein influences the rate of muscle growth in the rat. The rate of protein deposition in muscle will reflect both the ability of the diet to provide substrate for growth, as well as its ability to evoke a regulatory response which activates the anabolic processes involved in growth. The first of these factors will depend not only on the dietary protein concentration, but also on the amount of food consumed. Growth suppression is to be expected with very-low-protein diets or with food restriction, but increased intakes of marginally-protein-deficient diets could to some extent compensate for the deficiency and provide sufficient protein which, if utilized efficiently, would allow near normal growth. Previous studies show that food intakes of animals fed on protein-deficient diets can vary from normal or reduced intakes (Laurent et al. 1984; Harri \& Brockway, 1985) to increased intakes (Gurr et al. 1980; Lunn \& Austin, 1983; Swick \& Gribskov, 1983; Rothwell et al. 1983; Coyer et al. 1987). Since reduced body-weight growth and protein deposition were reported in all these studies it can be assumed that growth was limited by the regulatory response to the dietary protein:energy $(\mathrm{P}: \mathrm{E})$ ratio as well as by the absolute protein intake.

Dietary protein could exert a regulatory influence through its effect on tissue amino acid levels, although we have previously argued that there is little evidence for such action in 
muscle (Millward et al. 1976). Of the hormones which could mediate any regulatory responses in muscle exerted by the dietary P:E ratio, both insulin and thyroid hormones are likely candidates. Insulin secretion is sensitive to hepatic portal amino acid concentrations (Fajans \& Floyd, 1972) as well as a complex array of other signals (Berthoud, 1984), and is consequently markedly influenced by the dietary P:E ratio (Edozien et al. 1978). Insulin also plays a key role in the regulation of protein deposition, through its influence on protein synthesis in muscle (Waterlow et al. 1978; Jefferson, 1980) which is reduced by protein-deficient diets (Garlick et al. 1975; Millward et al. 1975; Waterlow et al. 1978). Insulin is also thought to influence proteolysis in muscle but recent reports of a stimulatory influence (Palmer et al. 1985; Palmer, 1987), in sharp contrast to its widely-assumed inhibitory influence (Goldberg, 1979), raise important new questions about its actual physiological role.

Thyroid hormones are also likely to play a key role. Changes in thyroid hormones could influence protein deposition in muscle because of their influence on both muscle protein synthesis (Brown et al. 1981, 1983) and protein degradation (DeMartino \& Goldberg, 1978; Brown \& Millward, 1983; Zeman et al. 1986). Thus the fall in plasma free 3,5,3'triiodothyronine $\left(T_{3}\right)$ levels in severely-protein-deficient rats (Cox et al. 1984) could mediate the fall in both muscle protein synthesis and degradation in such animals (Millward et al. 1975; Garlick et al. 1975). However it is by no means clear how the induction of parallel changes in protein synthesis and degradation by $T_{3}$ can influence net protein balance. In addition, thyroid hormones have been implicated in the regulation of energy balance during protein deficiency, particularly when there is a need to dispose of some of the extra energy associated with low P:E ratios in terms of thermogenesis (Tulp et al. 1979; Gurr et al. 1980; Rothwell et al. 1983).

We have therefore investigated, in a series of experiments using diets marginally and severely deficient in protein, the responses of muscle growth, protein turnover, plasma insulin and plasma free $\mathrm{T}_{3}$ to protein deficiency to determine the potential involvement of insulin and $T_{3}$ in mediating any influences of dietary protein deficiency on muscle growth and protein turnover.

\section{MATERIALS AND METHODS}

\section{Animals, diets and experimental design}

The composition of the diets is shown in Table 1 . The dietary protein concentrations were chosen so that the $80 \mathrm{~g}$ casein $/ \mathrm{kg}$ diet was below the optimum for maximum growth but contained sufficient protein theoretically to allow substantial growth if intakes were increased. The $45 \mathrm{~g}$ casein $/ \mathrm{kg}$ diet was chosen as a maintenance diet, whilst the protein-free diet was used to indicate the response to the most severe deficiency. These diets were fed ad lib. to male Sprague-Dawley COBS rats purchased from either Charles River (Margate, Kent) or Olac (Bicester, Oxon). Animals were purchased from the supplier at approximately $45-75 \mathrm{~g}$ and then allowed to acclimatize to the animal-house conditions for a minimum of $4 \mathrm{~d}$ before being randomly assigned to the various dietary groups appropriate to each experiment. The control group in each experiment was an age control fed on the $180 \mathrm{~g}$ casein $/ \mathrm{kg}$ diet (AC, $180 \mathrm{~g}$ casein $/ \mathrm{kg}$ ); in some experiments a baseline group of animals was killed at the start of the dietary period (BL, $180 \mathrm{~g}$ casein $/ \mathrm{kg}$ ), this enabled changes in the various measured variables with age to be distinguished from those due to the diets. The rats were caged inidividually unless otherwise indicated, at $24^{\circ}$, with a $12 \mathrm{~h}$ light $-12 \mathrm{~h}$ dark cycle (08.00-20.00 hours) and with access to water and food at all times. Daily $(24 \mathrm{~h})$ food intakes were measured taking into account spillage. The results were calculated as both $\mathrm{g} / \mathrm{d}$ and $\mathrm{g} / \mathrm{d}$ per $\mathrm{kg}$ body-weight ${ }^{0.56}$ (Cox et al. 1984). Rats were given the diets ad lib. for long enough (10-16 d, see Table 2, p. 401) to allow reasonable adaptation to the low-protein diets. Four experiments were performed (M1-M4); Expt M2 
Table 1. Composition of diets $(\mathrm{g} / \mathrm{kg})$

\begin{tabular}{lrrrc}
\hline \hline Diet (g casein/ & 180 & 80 & 45 & 0 \\
$\mathrm{~kg}) \ldots$ & 516 & 579 & 653 & 698 \\
Maize starch & 181 & 81 & 45 & - \\
Casein & 109 & 122 & 109 & 109 \\
Glucose & 91 & 102 & 91 & 91 \\
Solkafloc & 36 & 41 & 36 & 36 \\
Salt mix & 20 & 20 & 20 \\
Vitamin mix $\dagger$ & 20 & 2 & 1 & -45 \\
L-Methionine & 2 & 51 & 45 & 45 \\
Maize oil & 45 & & \\
\hline
\end{tabular}

All diets provided approximately $14.7 \mathrm{~kJ}(3.5 \mathrm{kcal}) / \mathrm{g}$.

* Bernhardt \& Tomarelli (1966).

$\dagger$ Vitamin mix (Special Diet Services, Witham, Essex) contained (g/ $\mathrm{kg}$ ) : vitamin A concentrate (200000 units/ g, $60 \mathrm{mg}$ retinol $/ \mathrm{g}$ ) $4 \cdot 5$, vitamin D concentrate $(400000$ units $/ \mathrm{g} ; 10 \mathrm{mg}$ cholecalciferol $/ \mathrm{g}) 0 \cdot 25, \alpha$-tocopherol $5 \cdot 0$, ascorbic acid 45.0, inositol 5.0, choline chloride 75.0, menadione $2 \cdot 25$, p-amino benzoic acid 5.0, niacin 4.5, riboflavin $1 \cdot 0$, pyridoxine hydrochloride $1 \cdot 0$, thiamin hydrochloride $1 \cdot 0$, calcium pantothenate $3 \cdot 0,(\mathrm{mg} / \mathrm{kg})$ : biotin $20 \cdot 0$, folic acid $90 \cdot 0$, vitamin $B_{12} 1 \cdot 35$

was performed in order to increase the total number of replicate measurements obtained in Expt M1. However, because food intakes in Expt M2 differed from those in Expt M1, we conducted further experiments with the $45 \mathrm{~g}$ casein $/ \mathrm{kg}$ diet (M3), and the $80 \mathrm{~g}$ casein/ $\mathrm{kg}$ diet (M4). In addition in Expt M4, to determine whether caging the rats in pairs influenced the food intake and growth responses to the marginally-low-protein diet, each dietary group was duplicated; one group was housed in pairs and the other singly. Because the distribution of food between individual animals of each pair was unknown, measurements of plasma hormones and protein turnover were only made in the singlycaged animals. Although the variability of the food intake was unexpected, it allowed a more detailed analysis of the relation between dietary protein and energy intakes, insulin and $T_{3}$ levels, muscle protein deposition and turnover.

\section{Protein turnover}

Protein synthesis rates were measured in vivo by the large-dose phenylalanine method (Garlick et al. 1980) modified as described previously (Jepson et al. 1986). Rats were injected into either a lateral tail vein (intravenous (iv); Expts M1 and M2) or intraperitoneum (ip; Expts M3 and M4), with a flooding dose of radioactively-labelled phenylalanine (iv injection containing $50 \mu \mathrm{Ci}$ and $150 \mu \mathrm{mol} / \mathrm{ml}$ in saline $(9 \mathrm{~g}$ sodium chloride $/ \mathrm{l}), 10 \mathrm{ml} / \mathrm{kg}$ body-weight; ip injection containing $20 \mu \mathrm{Ci}$ and $150 \mu \mathrm{mol} / \mathrm{ml}$ in saline, $20 \mathrm{ml} / \mathrm{kg}$ body-weight; Amersham International plc, Amersham, Bucks). At 10 (iv) or 15 (ip) min after injection, rats were decapitated and blood collected from the neck. Plasma was stored at $-20^{\circ}$ until required for hormone assays. Muscles (combined gastrocnemius and plantaris) were rapidly dissected, blotted, weighed and stored in liquid nitrogen.

The specific radioactivity of free and protein-bound phenylalanine was determined and protein synthesis calculated as described previously (Garlick et al. 1980; Jepson et al. 1986).

Protein degradation was measured as the difference between the synthesis rate and change in muscle protein mass as previously described and discussed (Millward et al. 1975; Odedra et al. 1983; Jepson et al. 1986; Giugliano \& Millward, 1986):

$$
K_{\mathrm{d}}=K_{\mathrm{s}}-K_{\mathrm{g}}
$$


where $K_{\mathrm{d}}, K_{\mathrm{s}}$ and $K_{\mathrm{g}}$ are the rates of degradation, synthesis and growth (\%/d) respectively of muscle protein.

The muscle-protein growth rate was calculated from the individual values of the growth in body-weight over $24 \mathrm{~h}$ before measurement of protein synthesis, taking into account any change in the muscle protein mass:body-weight ratio (MP:W) which was likely to have occurred during this time. This latter component was calculated from the change in MP:W during the experimental period when any change occurred. Although we have not systematically studied the rate of change of body composition on low-protein diets, from our experience we believe it can be reasonably assumed that any changes in body composition which influenced this ratio occur uniformly throughout the experimental period. Thus this component of muscle growth over the $24 \mathrm{~h}$ before death was calculated from the percentage change in MP:W over the experimental period divided by the time in days. Although this calculation results in a fractional growth rate which is greater than if the calculation is done on the assumption that the change in body composition occurred exponentially (i.e. $\mathrm{MP}: \mathrm{W}_{t-t}=\mathrm{MP}: \mathrm{W}_{t=0} \mathrm{e}^{k t}$ where $k$ is the first-order rate-constant describing the rate of change of MP:W over the time $t)$ the difference is small $(12 \%$ in the worst case) and will not influence the present results. This value for the mean daily change in body composition was then added to the observed (percentage) body-weight growth rate over the $24 \mathrm{~h}$ before death to obtain the overall growth rate $(\% / \mathrm{d})$.

Protein and RNA concentrations were determined as described previously (Millward et al. 1974) and the RNA activity or $K_{\mathrm{RNA}}$ (g protein synthesis/g RNA per d) calculated from $K_{\mathrm{s}}$ and the RNA:protein ratio.

\section{Plasma hormones}

Plasma insulin was measured using a charcoal-separation immunoassay (Odedra et al. 1982), while free and total $T_{3}$ were measured by liso-phase radioimmunoassay kits (Metachem Diagnostics, Northampton).

\section{Statistics}

All results are presented as mean values and standard deviations. Statistical analysis was by one-way analysis of variance, and by Student's $t$ test where appropriate. Correlations between two variables were assessed by calculation of the correlation coefficient, $r$. In those circumstances where there was good reason to expect that correlation between two variables was a result of their correlation with a third, partial correlation analysis was performed (see Snedecor \& Cochran, 1967). This allows the correlation between two variables $(i$ and $j$ ) to be determined whilst controlling for the influence of a third $(k)$ and was calculated from the correlation coefficients $(r)$ according to the formula:

$$
r_{i j . k}=\frac{r_{i j}-\left(r_{i k}\right)\left(r_{j k}\right)}{\sqrt{ }\left(1-r_{i k}^{2}\right) \sqrt{ }\left(1-r_{j k}^{2}\right)} .
$$

In some cases where a fourth variable was judged likely to interact the second-order partial correlation coefficient $\left(r_{i j . l(k)}\right)$ was also calculated by substituting the appropriate first-order partial coefficients, $r_{i j . k}$, for $r_{i j}$ in the equation.

In all significance tests, $P \leqslant 0.05$ was taken to be significant.

\section{RESULTS}

Food intake and body-weight growth

Food intake was measured throughout each experiment. We report here (Table 2) intakes after $7 \mathrm{~d}$ and during the $24 \mathrm{~h}$ before death, together with initial and final body- 
Table 2. Body-weights $(W)$ and food intakes of animals $\dagger$ fed on diets of varying protein concentrations

(Mean values and standard deviations)

\begin{tabular}{|c|c|c|c|c|c|c|c|c|c|c|c|c|c|c|c|}
\hline \multirow{4}{*}{$\begin{array}{c}\text { Expt } \\
\text { no. }\end{array}$} & \multirow{4}{*}{$\begin{array}{c}\text { Diet } \\
\text { (g casein } / \mathrm{kg})\end{array}$} & \multirow{4}{*}{\multicolumn{2}{|c|}{$\begin{array}{cc} & \text { Period } \\
& \text { on } \\
& \text { diet } \\
n & \text { (d) }\end{array}$}} & & & & & \multicolumn{8}{|c|}{ Food intakes } \\
\hline & & & & \multicolumn{4}{|c|}{ w } & \multicolumn{4}{|c|}{ Day 7} & \multicolumn{4}{|c|}{ Final day } \\
\hline & & & & \multicolumn{2}{|c|}{$\begin{array}{c}\text { Initial } \\
(\mathrm{g})\end{array}$} & \multicolumn{2}{|c|}{$\begin{array}{c}\text { Final } \\
(\mathrm{g})\end{array}$} & \multicolumn{2}{|c|}{$\begin{array}{l}\mathrm{g} / \mathrm{kg} \mathrm{W}^{0.56} \\
\text { per d }\end{array}$} & \multicolumn{2}{|c|}{$(g / d)$} & \multicolumn{2}{|c|}{$\begin{array}{c}\mathrm{g} / \mathrm{kg} \mathrm{W}^{0.56} \\
\text { per } \mathrm{d}\end{array}$} & \multicolumn{2}{|c|}{$(g / d)$} \\
\hline & & & & Mean & SD & Mean & $\mathrm{SD}$ & Mean & $\mathrm{SD}$ & Mean & $\mathrm{SD}$ & Mean & $\mathrm{SD}$ & Mean & $\mathrm{SD}$ \\
\hline \multirow[t]{4}{*}{ Ml† } & 180 & 6 & 16 & 74 & 5 & 188 & 23 & 53.9 & $5 \cdot 4$ & $16 \cdot 4$ & $2 \cdot 3$ & $59 \cdot 5$ & $6 \cdot 3$ & $22 \cdot 4$ & $3 \cdot 7$ \\
\hline & 80 & 6 & - & - & - & 114 & 10 & $55 \cdot 0$ & $9 \cdot 1$ & $14 \cdot 2$ & $2 \cdot 4$ & $54 \cdot 8$ & $5 \cdot 0$ & $16 \cdot 0^{*}$ & $2 \cdot 0$ \\
\hline & 45 & 6 & - & - & - & 81 & 6 & $44 \cdot 3^{*}$ & $6 \cdot 7$ & $10 \cdot 7^{*}$ & $1 \cdot 7$ & $37 \cdot 9^{*}$ & 3.5 & $9 \cdot 3^{*}$ & 0.8 \\
\hline & 0 & 6 & - & - & - & 56 & 4 & $33 \cdot 4^{*}$ & $10 \cdot 1$ & $7 \cdot 1^{*}$ & $2 \cdot 0$ & $31 \cdot 7^{*}$ & $5 \cdot 0$ & $6 \cdot 4^{*}$ & $1 \cdot 2$ \\
\hline \multirow[t]{3}{*}{$\mathrm{M} 2+$} & 180 & 6 & 14 & 89 & 7 & 195 & 8 & $50 \cdot 6$ & $3 \cdot 8$ & 16.8 & $1 \cdot 2$ & $50 \cdot 9$ & 3.2 & $20 \cdot 3$ & 1.6 \\
\hline & 80 & 6 & - & - & - & 180 & 13 & $61 \cdot 8^{*}$ & $5 \cdot 0$ & $20 \cdot 0^{*}$ & $1 \cdot 5$ & $57 \cdot 5^{*}$ & $4 \cdot 3$ & $22 \cdot 1$ & $2 \cdot 0$ \\
\hline & 45 & 6 & - & - & - & 92 & 6 & $33 \cdot 3^{*}$ & $4 \cdot 3$ & $8 \cdot 7^{*}$ & 1.0 & $27 \cdot 6^{*}$ & $6 \cdot 1$ & $7 \cdot 3^{*}$ & 1.5 \\
\hline \multirow[t]{2}{*}{ M3§ } & 180 & 4 & 10 & 90 & 5 & 168 & 6 & $53 \cdot 7$ & $7 \cdot 7$ & 17.8 & 2.8 & $60 \cdot 1$ & $7 \cdot 2$ & $21 \cdot 7$ & $3 \cdot 4$ \\
\hline & 45 & 5 & - & - & - & 121 & 6 & $64 \cdot 0^{*}$ & $6 \cdot 3$ & $18.9 *$ & $2 \cdot 2$ & $68 \cdot 1^{*}$ & $5 \cdot 3$ & 210 & 1.5 \\
\hline \multirow[t]{2}{*}{ M48 } & 180 & 6 & 10 & 90 & 7 & 168 & 9 & $45 \cdot 7$ & $4 \cdot 1$ & 15.4 & 1.4 & $48 \cdot 6$ & 3.5 & $17 \cdot 8$ & 1.4 \\
\hline & 80 & 8 & - & - & - & 154 & 15 & $57 \cdot 4^{*}$ & $7 \cdot 7$ & $18.7^{*}$ & $2 \cdot 9$ & $63 \cdot 7^{*}$ & $9 \cdot 8$ & $22 \cdot 6$ & $4 \cdot 3$ \\
\hline Paired & 180 & 6 & - & - & - & 170 & 15 & 43.9 & $2 \cdot 1$ & $14 \cdot 5$ & 0.3 & 53.5 & $2 \cdot 4$ & $18 \cdot 5$ & 0.6 \\
\hline Paired & 80 & 8 & - & - & $\ldots$ & 148 & 19 & $57 \cdot 8^{*}$ & $2 \cdot 8$ & $18 \cdot 7^{*}$ & 1.0 & $65 \cdot 4^{*}$ & $6 \cdot 2$ & $21 \cdot 5$ & 2.9 \\
\hline
\end{tabular}

Significantly different from respective $180 \mathrm{~g}$ casein $/ \mathrm{kg}$ diet group: $* P<0.05$.

+ Animals housed in single cases except as indicated in Expt M4 (see p. 399).

† Animals from Charles River (Margate, Kent).

$\S$ Animals from Olac (Bicester, Oxon).

weights. We have calculated intakes in terms of metabolic body size $\left(\mathrm{g} / \mathrm{kg}\right.$ body-weight ${ }^{0.56}$ per $\mathrm{d})$, as well as presenting absolute intakes $(\mathrm{g} / \mathrm{d})$.

The response to the $80 \mathrm{~g}$ casein $/ \mathrm{kg}$ diet was variable on the three occasions when it was offered. Thus for intakes expressed in terms of metabolic body size, and in comparison with the $180 \mathrm{~g}$ casein $/ \mathrm{kg}$ diet groups, rats exhibited eventual slight reductions in intake in Expt M1 and increased intakes in Expts M2 and M4. As a result of these different food intakes the growth responses were also variable, with impaired growth in Expt M1, but near normal growth in the groups which exhibited the hyperphagia (Expts M2 and M4). The housing of the animals in pairs as opposed to singly (in Expt M4) did not markedly influence the food intake or growth rate, so that the hyperphagic response was apparent in both groups.

The response to the $45 \mathrm{~g}$ casein $/ \mathrm{kg}$ diet was either anorexia (Expts M1 and M2) associated with complete suppression of growth, or hyperphagia (Expt M3) which did allow some growth. Nevertheless the final body-weights were still approximately $30 \%$ less than the control values.

There was marked anorexia in response to the $0 \mathrm{~g}$ casein $/ \mathrm{kg}$ diet, with food intake falling to only $40-50 \%$ of the control value. There was gradual weight loss and after $16 \mathrm{~d}$ the mean body-weight of the group was $24 \%$ lower than the mean starting weight.

When the food intakes are not corrected for metabolic body size, the conclusions were essentially the same except that in Expt Ml the absolute intake $(\mathrm{g} / \mathrm{d})$ of the $80 \mathrm{~g}$ casein $/ \mathrm{kg}$ diet group was significantly lower than the control value, and in Expt M3 the intake of the $45 \mathrm{~g}$ casein $/ \mathrm{kg}$ diet group was comparable to control values rather than elevated. 
Table 3. Insulin ( $\mu$ Units $/ \mathrm{ml})$, free 3,5,3'-triiodothyronine $\left(T_{3} ; \mathrm{pg} / \mathrm{ml}\right)$ and total $T_{3}(\mathrm{ng} / \mathrm{ml})$ concentrations in rats fed on diets of varying protein concentrations

(Mean values and standard deviations)

\begin{tabular}{|c|c|c|c|c|c|c|c|c|}
\hline \multirow{3}{*}{$\begin{array}{c}\text { Expt } \\
\text { no. }\end{array}$} & \multirow{3}{*}{\multicolumn{2}{|c|}{$\begin{array}{c}\text { Diet } \\
(\mathrm{g} \text { casein } / \mathrm{kg})\end{array}$}} & & & \multicolumn{4}{|c|}{$\mathrm{T}_{3}$} \\
\hline & & & \multicolumn{2}{|c|}{ Insulin } & \multicolumn{2}{|c|}{ Free } & \multicolumn{2}{|c|}{ Total } \\
\hline & & & Mean & $\mathrm{SD}$ & Mean & $\mathrm{SD}$ & Mean & SD \\
\hline M1 & $\begin{array}{l}\mathrm{BL} \\
\mathrm{AC}\end{array}$ & $\begin{array}{r}180 \\
180 \\
80 \\
45 \\
0\end{array}$ & $\begin{array}{c}18 \cdot 6 \\
42 \cdot 8 \\
25 \cdot 9^{*} \\
17 \cdot 4^{*} \\
7 \cdot 0^{*}\end{array}$ & $\begin{array}{l}3.2 \\
4.3 \\
6.2 \\
1.9 \\
1.6\end{array}$ & $\begin{array}{l}9 \cdot 7 \\
7 \cdot 7 \\
5 \cdot 3^{*} \\
3 \cdot 7^{*} \\
4 \cdot 2^{*}\end{array}$ & $\begin{array}{l}0.5 \\
0.6 \\
0.4 \\
0.5 \\
0.7\end{array}$ & $\begin{array}{l}1.62 \\
0.97 \\
1.29 \\
1.05 \\
1.80^{*}\end{array}$ & $\begin{array}{l}0 \cdot 28 \\
0.20 \\
0 \cdot 17 \\
0 \cdot 14 \\
0 \cdot 30\end{array}$ \\
\hline M2 & $\begin{array}{l}\mathrm{BL} \\
\mathrm{AC}\end{array}$ & $\begin{array}{r}180 \\
180 \\
80 \\
45\end{array}$ & $\begin{array}{l}35 \cdot 9 \\
55 \cdot 8 \\
40 \cdot 6^{*} \\
23 \cdot 2^{*}\end{array}$ & $\begin{array}{l}9 \cdot 9 \\
4 \cdot 6 \\
4 \cdot 6 \\
2 \cdot 2\end{array}$ & $\begin{array}{l}9 \cdot 6 \\
8.9 \\
7 \cdot 1^{*} \\
3 \cdot 6^{*}\end{array}$ & $\begin{array}{l}0.4 \\
0.6 \\
0.5 \\
0.4\end{array}$ & $\begin{array}{l}1 \cdot 17 \\
0.98 \\
1 \cdot 14 \\
1 \cdot 18\end{array}$ & $\begin{array}{l}0 \cdot 11 \\
0 \cdot 08 \\
0 \cdot 18 \\
0 \cdot 18\end{array}$ \\
\hline M3 & $\mathrm{AC}$ & $\begin{array}{r}180 \\
45\end{array}$ & $\begin{array}{l}39 \cdot 8 \\
31 \cdot 0\end{array}$ & $\begin{array}{l}2 \cdot 9 \\
2 \cdot 5\end{array}$ & $\begin{array}{l}7 \cdot 3 \\
5 \cdot 3^{*}\end{array}$ & $\begin{array}{l}0.8 \\
0.2\end{array}$ & $\begin{array}{l}1.46 \\
1.91^{*}\end{array}$ & $\begin{array}{l}0.11 \\
0.21\end{array}$ \\
\hline M4 & $\begin{array}{l}\text { BL } \\
\mathrm{AC}\end{array}$ & $\begin{array}{r}180 \\
180 \\
80\end{array}$ & $\begin{array}{l}41 \cdot 0 \\
48 \cdot 4 \\
32 \cdot 9^{*}\end{array}$ & $\begin{array}{r}13 \cdot 0 \\
7 \cdot 7 \\
6 \cdot 4\end{array}$ & $\begin{array}{l}7.9 \\
7.9 \\
6.7 *\end{array}$ & $\begin{array}{l}0.6 \\
0.5 \\
0.7\end{array}$ & $\begin{array}{l}1.78 \\
1.33 \\
1.79^{*}\end{array}$ & $\begin{array}{l}0 \cdot 09 \\
0 \cdot 18 \\
0 \cdot 14\end{array}$ \\
\hline
\end{tabular}

$\mathrm{BL}(180 \mathrm{~g}$ casein $/ \mathrm{kg}$ diet group), baseline animals killed at the start of the dietary period; $\mathrm{AC}$ ( $180 \mathrm{~g} \mathrm{casein} / \mathrm{kg}$ diet group), age controls killed at the end of the dietary period, at the same time as experimental diet groups.

Significantly different from $\mathrm{AC} 180 \mathrm{~g}$ casein $/ \mathrm{kg}$ diet group: ${ }^{*} P<0.05$.

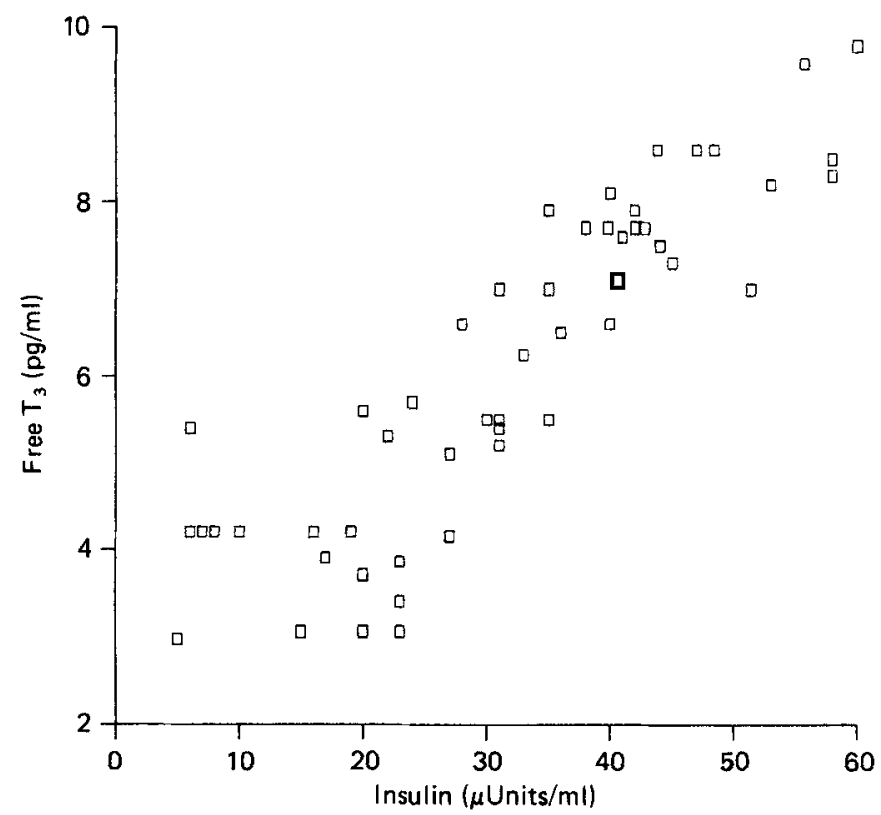

Fig. 1. Relation between plasma free 3,5,3'-triiodothyronine $\left(\mathrm{T}_{3} ; \mathrm{pg} / \mathrm{ml}\right)$ and insulin $(\mu \mathrm{Units} / \mathrm{ml})$ in rats of similar ages fed on diets of varying protein concentrations (for details, see p. 398). 


\section{Insulin and $T_{3}$}

Plasma insulin concentration increased with age in control rats in Expts M1 and M2, although the increase was not significant in Expt M4 (Table 3). It was apparent from comparisons between the groups at the end of the treatment periods that insulin was depressed in all low-protein-diet groups, regardless of the food intake response, with the lowest values in the protein-free-diet group.

As reported previously (Smallidge et al. 1982; Cox et al. 1984) the assessment of thyroid hormone status is complicated because differential changes in free and total $T_{3}$ occur in rats fed on low-protein diets. Total $\mathrm{T}_{3}$ was elevated in response to protein deficiency (Table 3) particularly in the group fed on the protein-free diet (Expt M1), where it was $86 \%$ higher than age controls ( $\mathrm{AC}, 180 \mathrm{~g}$ casein $/ \mathrm{kg}$ ). In groups fed on the 80 and $45 \mathrm{~g}$ casein $/ \mathrm{kg}$ diets, the increase ranged between 8 and $35 \%$ above respective age controls, with no clear-cut distinction between anorexic and hyperphagic groups. Thus the concentration of total $\mathrm{T}_{3}$ bore no clear relation to food intakes or growth rate. In contrast plasma free $T_{3}$ concentration fell in response to low-protein diets in a similar way to insulin. The fall was more marked in the anorexic, slower-growing groups $(80 \mathrm{~g} / \mathrm{kg}$ Expt M1, $45 \mathrm{~g} / \mathrm{kg}$ Expts M1 and $\mathrm{M} 2,0 \mathrm{~g} / \mathrm{kg}$ Expt M1) than in the hyperphagic rats $(80 \mathrm{~g} / \mathrm{kg}$ Expts $\mathrm{M} 2$ and $\mathrm{M} 4,45 \mathrm{~g} /$ $\mathrm{kg}$ Expt M3). The relation between insulin and free $T_{3}$ is shown in Fig. 1, and between dietary protein and non-protein-energy intakes and hormone levels in individual animals in Fig. 2.

\section{Muscle growth}

The ratios of muscle weight (and in some cases skinned eviscerated carcass weight): total body-weight (Table 4), can be used as indicators of any major changes in muscle growth with respect to whole body growth. There was an age-related increase in the muscle mass:body-weight ratio over the 14 and $16 \mathrm{~d}$ experiments (M1 and M2), as previously documented (Miller, 1969), although this was not evident over the $10 \mathrm{~d}$ in Expts M3 and M4. In rats fed on the $80 \mathrm{~g}$ casein $/ \mathrm{kg}$ diet there was no significant change in the muscle mass : body-weight ratio compared with age control animals, although there was a tendency towards a lower ratio in those groups where the food intake was increased (Expts M2 and M4), and near-normal growth occurred. However the carcass: body-weight ratio was the same as that for age controls in both Expt M1, where growth was impaired, and in Expt M2, where growth was normal.

In rats fed on the $45 \mathrm{~g}$ casein $/ \mathrm{kg}$ diet and which responded with anorexia and growthsuppression (Expts M1 and M2) a leaner body composition than that of age controls was indicated, in that both carcass : body-weight and muscle: body-weight ratios were increased. These changes were not evident in the hyperphagic $45 \mathrm{~g}$ casein $/ \mathrm{kg}$ diet groups (Expt M3) where the carcass formed a lower proportion of body-weight, with the same trend seen for muscle (although not statistically significant). This points towards the deposition of the excess energy intake as fat.

\section{Muscle protein turnover}

The replacement of muscle protein was faster during rapid growth, falling as the growth rate fell with age or due to protein deficiency as previously shown (Millward et al. 1975). Linear regression of the fractional growth rate $\left(K_{\mathrm{g}}\right)$ with the rate of protein synthesis $\left(K_{\mathrm{s}}\right)$ indicated a slope of 0.47 (SD 0.05) suggesting that unit gain of muscle protein necessitated synthesis of about twice the amount of protein.

The influence of protein deficiency on protein synthesis $\left(K_{\mathrm{s}}\right)$ and degradation $\left(K_{\mathrm{d}}\right)$ 

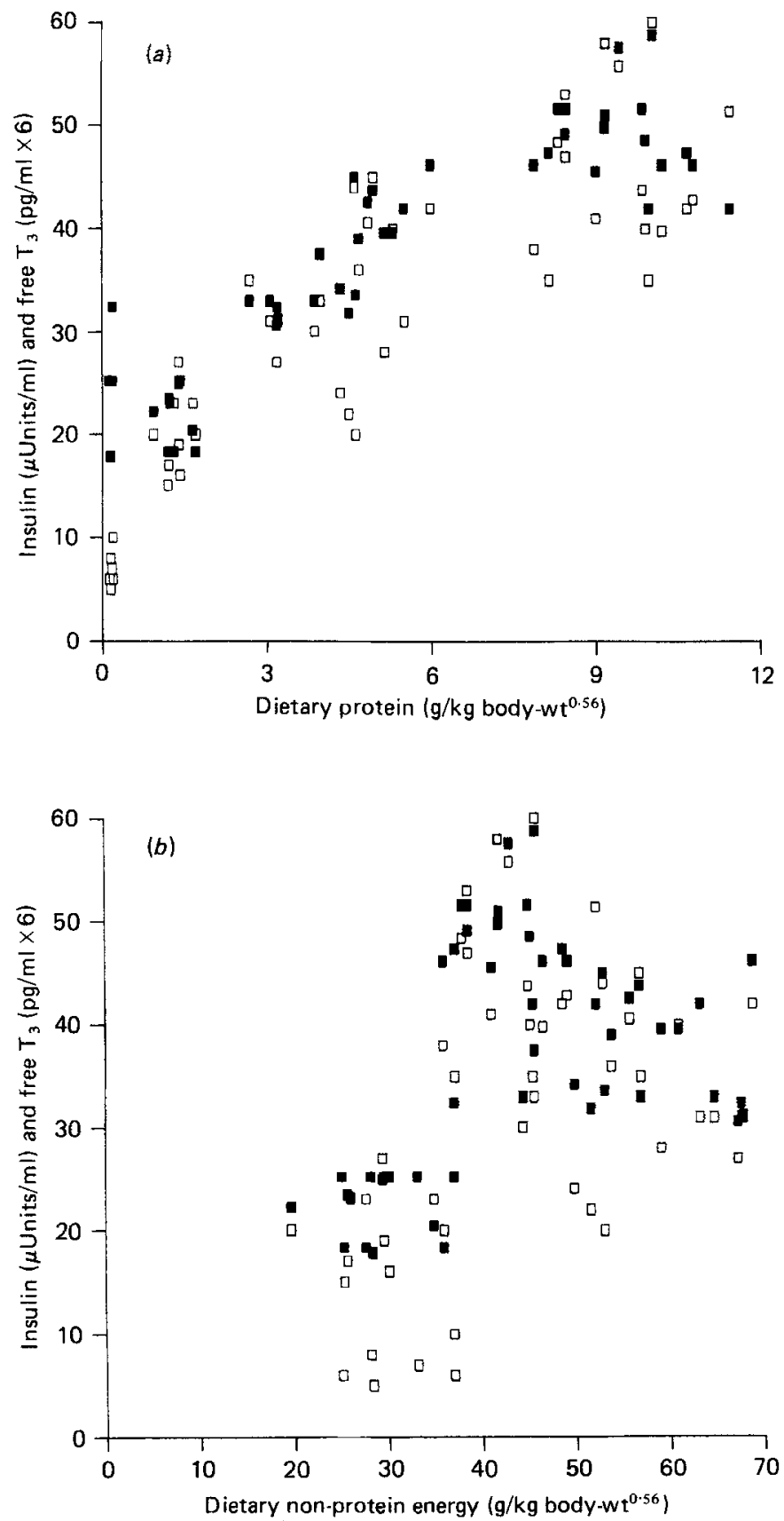

Fig. 2. Relation between plasma free $3,5,3^{\prime}$-triiodothyronine $\left(\mathrm{T}_{3} ; \mathrm{pg} / \mathrm{ml} \times 6\right)(\boldsymbol{\square})$, insulin $(\mu \mathrm{Units} / \mathrm{ml})$ $(\square)$ and $(a)$ dietary protein $\left(\mathrm{g} / \mathrm{kg}\right.$ body-weight $\left.{ }^{0.56}\right)$, and $(b)$ non-protein energy $\left(\mathrm{g} / \mathrm{kg}\right.$ body-weight $\left.{ }^{0.56}\right)$, in rats of similar ages fed on diets of varying protein concentrations (for details, see p. 398). 
Table 4. Body composition at death of rats fed on diets of varying protein concentrations (Mean values and standard deviations)

\begin{tabular}{|c|c|c|c|c|c|c|}
\hline \multirow{2}{*}{$\begin{array}{c}\text { Expt } \\
\text { no. }\end{array}$} & \multirow{2}{*}{\multicolumn{2}{|c|}{$\begin{array}{c}\text { Diet } \\
\text { (g casein } / \mathbf{k g})\end{array}$}} & \multicolumn{2}{|c|}{$\begin{array}{c}\text { Carcass } \ddagger \\
(\mathrm{g} / \mathrm{kg} \text { body-wt) }\end{array}$} & \multicolumn{2}{|c|}{$\begin{array}{c}\text { Muscle } \$ \\
\text { (g/kg body-wt) }\end{array}$} \\
\hline & & & Mean & sD & Mean & SD \\
\hline M1 & $\begin{array}{l}\mathrm{BL} \\
\mathrm{AC}\end{array}$ & $\begin{array}{r}180 \\
180 \\
80 \\
45 \\
0\end{array}$ & $\begin{array}{l}\overline{-} \\
505 \\
523 \\
545^{*} \\
544^{*}\end{array}$ & $\begin{array}{l}- \\
25 \\
10 \\
22 \\
26\end{array}$ & $\begin{array}{l}5 \cdot 2 \\
5 \cdot 6^{\dagger} \\
5 \cdot 4 \\
5 \cdot 7 \dagger \\
5 \cdot 4\end{array}$ & $\begin{array}{l}0.3 \\
0.5 \\
0.2 \\
0.3 \\
0.6\end{array}$ \\
\hline $\mathrm{M} 2$ & $\begin{array}{l}\mathrm{BL} \\
\mathrm{AC}\end{array}$ & $\begin{array}{r}180 \\
180 \\
80 \\
45\end{array}$ & $\begin{array}{l}-\overline{452} \\
440 \\
483^{*}\end{array}$ & $\begin{array}{l}\overline{12} \\
14 \\
19\end{array}$ & $\begin{array}{l}4.5 \\
5 \cdot 4 \dagger \\
5 \cdot 0^{\dagger} \\
5 \cdot 7 \dagger\end{array}$ & $\begin{array}{l}0.2 \\
0.2 \\
0.2 \\
0.2\end{array}$ \\
\hline M3 & $\mathrm{AC}$ & $\begin{array}{r}180 \\
45\end{array}$ & $\begin{array}{l}443 \\
414^{*}\end{array}$ & $\begin{array}{l}16 \\
11\end{array}$ & $\begin{array}{l}5 \cdot 4 \\
4 \cdot 8\end{array}$ & $\begin{array}{l}0 \cdot 2 \\
0 \cdot 2\end{array}$ \\
\hline M4 & $\begin{array}{c}\text { BL } \\
\text { AC } \\
\text { Pair } \\
\text { Pair }\end{array}$ & $\begin{array}{r}180 \\
180 \\
80 \\
180 \\
80\end{array}$ & $\begin{array}{l}- \\
- \\
-\end{array}$ & $\begin{array}{l}- \\
- \\
- \\
-\end{array}$ & $\begin{array}{l}4 \cdot 5 \\
4 \cdot 4 \\
4 \cdot 1 \\
4 \cdot 4 \\
4 \cdot 1\end{array}$ & $\begin{array}{l}0.6 \\
0.2 \\
0 \cdot 3 \\
0.3 \\
0.4\end{array}$ \\
\hline
\end{tabular}

BL (180 g casein $/ \mathrm{kg}$ diet group), baseline animals killed at the start of the dietary period; $\mathrm{AC}$ ( $180 \mathrm{~g} \mathrm{casein} / \mathrm{kg}$ diet group), age controls killed at the end of the dietary period, at the same time as experimental diet groups; Pair ( 180 and $80 \mathrm{~g}$ casein $/ \mathrm{kg}$ diet groups), animals were caged in pairs.

Significantly different from $\mathrm{AC} 180 \mathrm{~g}$ casein $/ \mathrm{kg}$ diet group: ${ }^{*} P<0.05$

Significantly different from BL $180 \mathrm{~g}$ casein $/ \mathrm{kg}$ diet group: $\dagger P<0.05$.

Skinned, eviscerated.

$\S$ Muscle was combined gastrocnemius and plantaris.

(Table 5), varied according to the food intake. Thus in the absence of hyperphagia in the $80 \mathrm{~g}$ casein $/ \mathrm{kg}$ diet group (Expt M1), $K_{\mathrm{s}}$ was $31 \%$ lower than that in the age control group, and this was accompanied by an $18 \%$ lowering of $K_{\mathrm{d}}$. In Expts M2 and M4, where there was a hyperphagic response to the $80 \mathrm{~g}$ casein $/ \mathrm{kg}$ diet, both $K_{\mathrm{s}}$ and $K_{\mathrm{d}}$ were maintained at agecontrol values; hence the normal muscle growth rates seen in these groups.

In the $45 \mathrm{~g}$ casein $/ \mathrm{kg}$ diet group, $K_{\mathrm{s}}$ was reduced in every case. The fall was smallest in Expt M3 $(32 \%)$ where the rats were hyperphagic, compared with reductions of 50 and $55 \%$ in Expts M1 and M2 respectively. As with the $80 \mathrm{~g}$ casein $/ \mathrm{kg}$ diet, a reduction in $K_{\mathrm{s}}$ was associated with a reduction in $K_{\mathrm{d}}$ and the magnitude of the change in $K_{\mathrm{d}}$ varied directly with the food-intake response.

The lowest synthesis rate occurred in response to the $0 \mathrm{~g}$ casein $/ \mathrm{kg}$ diet. In this case the reduction in $K_{\mathrm{s}}$ was such that even with the fall in $K_{\mathrm{d}}$, the animals were in a catabolic state, losing muscle protein.

The control range of values for $K_{\mathrm{RNA}}$ (the synthesis rate per unit RNA) was 13.4-20.1 $\mathrm{g}$ protein/g RNA per d, similar to the range of values previously described (Millward \& Waterlow, 1978). This wide range of values in the well-fed animals tends to overshadow any effect of the low-protein diets since when the values for these animals were low, they tended to fall in the lower end of the control range as previously reported (Millward \& Waterlow, 1978). In each experiment, in comparison with the age-control groups, the $K_{\mathrm{RNA}}$ was unchanged in all groups fed on the $80 \mathrm{~g}$ casein $/ \mathrm{kg}$ diet, and with the $45 \mathrm{~g}$ casein $/ \mathrm{kg}$ diet, whilst mean values were generally lower, only in Expt M1 was the reduction statistically 
Table 5. Muscle growth and protein turnover in rats fed on diets of varying protein concentrations

(Mean values and standard deviations)

\begin{tabular}{|c|c|c|c|c|c|c|c|c|c|c|c|}
\hline \multirow{3}{*}{$\begin{array}{c}\text { Expt } \\
\text { no. }\end{array}$} & \multirow{3}{*}{$\begin{array}{c}\text { Diet } \\
\text { (g casein } / \mathrm{kg})\end{array}$} & \multicolumn{6}{|c|}{ Protein synthesis } & & & & \\
\hline & & \multicolumn{2}{|c|}{$\begin{array}{c}K_{\mathrm{s}} \\
(\% / \mathrm{d})\end{array}$} & \multicolumn{2}{|c|}{$\begin{array}{c}K_{\mathrm{HNA}} \\
\text { (g/g RNA } \\
\text { per d) }\end{array}$} & \multicolumn{2}{|c|}{$\begin{array}{l}\text { RNA: protein } \\
\text { (mg/g protein) }\end{array}$} & \multicolumn{2}{|c|}{$\begin{array}{c}\text { Growth } \\
K_{\mathrm{g}} \\
(\% / \mathrm{d})\end{array}$} & \multicolumn{2}{|c|}{$\begin{array}{c}\text { Degradation } \\
K_{\mathrm{d}} \\
(\% / \mathrm{d})\end{array}$} \\
\hline & & Mean & SD & Mean & $\mathrm{SD}$ & Mean & SD & Mean & SD & Mean & SD \\
\hline \multirow[t]{8}{*}{ M1 } & BL 180 & $23 \cdot 8$ & 1.9 & $19 \cdot 1$ & $2 \cdot 8$ & $12 \cdot 6$ & 1.7 & $10 \cdot 0$ & 0.4 & 13.8 & 1.9 \\
\hline & $\mathrm{AC} \quad 180$ & 14.0 & $1 \cdot 2$ & $13 \cdot 4$ & 1.6 & $10 \cdot 6$ & $1 \cdot 3$ & 4.9 & 0.4 & $9 \cdot 0$ & $1 \cdot 2$ \\
\hline & 80 & $9 \cdot 6$ & $1 \cdot 1$ & $14 \cdot 0$ & $4 \cdot 6$ & $7 \cdot 5$ & $2 \cdot 2$ & $2 \cdot 2$ & 0.8 & $7 \cdot 4$ & $0 \cdot 8$ \\
\hline & $\%$ change $\dagger$ & $-3 l^{*}$ & & +5 & & $-29^{*}$ & & $-55^{*}$ & & $-18^{*}$ & \\
\hline & 45 & $7 \cdot 0$ & 1.7 & 11.8 & $1 \cdot 3$ & 6.6 & $1 \cdot 2$ & 0.3 & $0 \cdot 9$ & $6 \cdot 6$ & 1.6 \\
\hline & $\%$ change & $-50^{*}$ & & $-12^{*}$ & & $-38^{*}$ & & $-93^{*}$ & & $-27^{*}$ & \\
\hline & 0 & $4 \cdot 0$ & $0 \cdot 2$ & $7 \cdot 5$ & 04 & $5 \cdot 3$ & 0.2 & $-0 \cdot 8$ & $0-1$ & $4 \cdot 8$ & $0 \cdot 1$ \\
\hline & $\%$ change & $-71^{*}$ & & $-44^{*}$ & & $-50^{*}$ & & $-116^{*}$ & & $-47^{*}$ & \\
\hline \multirow[t]{6}{*}{ M2 } & BL $\quad 180$ & $24 \cdot 1$ & 0.9 & $20 \cdot 1$ & $2 \cdot 7$ & $12 \cdot 0$ & $1 \cdot 1$ & $8 \cdot 0$ & $0 \cdot 9$ & $16 \cdot 1$ & $1 \cdot 2$ \\
\hline & $\mathrm{AC} \quad 180$ & $15 \cdot 7$ & 1.5 & $18 \cdot 2$ & $2 \cdot 7$ & 8.7 & 1.0 & $5 \cdot 0$ & $0 \cdot 3$ & $10 \cdot 5$ & $1 \cdot 5$ \\
\hline & 80 & $15 \cdot 3$ & $1 \cdot 1$ & 18.9 & 1.8 & $8 \cdot 4$ & 1.0 & $4 \cdot 4$ & 0.4 & $10 \cdot 9$ & $1 \cdot 1$ \\
\hline & $\%$ change & -3 & & +4 & & -3 & & -12 & & +4 & \\
\hline & 45 & 6.9 & 1.0 & $14 \cdot 7$ & 3.6 & $4 \cdot 8$ & 0.6 & $1 \cdot 3$ & 0.2 & $5 \cdot 5$ & $1 \cdot 0$ \\
\hline & $\%$ change & $-55^{*}$ & & -19 & & $-45^{*}$ & & $-73^{*}$ & & $-48^{*}$ & \\
\hline \multirow[t]{3}{*}{ M3 } & AC $\quad 180$ & $13 \cdot 6$ & 0.9 & 130 & 0.6 & 10.5 & 0.7 & $5 \cdot 3$ & 0.2 & $8 \cdot 4$ & 0.8 \\
\hline & 45 & $9 \cdot 2$ & 0.6 & $12 \cdot 8$ & 0.6 & $7 \cdot 2$ & 0.6 & 2.6 & 0.5 & $6 \cdot 6$ & $0 \cdot 6$ \\
\hline & $\%$ change & $-32^{*}$ & & -2 & & $-31^{*}$ & & $-51^{*}$ & & $-21^{*}$ & \\
\hline \multirow[t]{4}{*}{ M4 } & BL $\quad 180$ & $21 \cdot 5$ & $2 \cdot 2$ & 13.9 & $0 \cdot 3$ & $14 \cdot 8$ & 1.6 & $10 \cdot 0$ & 0.8 & $11 \cdot 6$ & 3.0 \\
\hline & AC $\quad 180$ & $15 \cdot 0$ & 1.9 & $13 \cdot 9$ & 1.8 & $10 \cdot 8$ & $0 \cdot 4$ & 4.8 & 0.2 & $10 \cdot 1$ & $2 \cdot 0$ \\
\hline & 80 & 13.9 & $1 \cdot 5$ & $13 \cdot 8$ & 1.7 & $10 \cdot 1$ & 0.7 & $5 \cdot 1$ & 0.4 & 8.8 & $1 \cdot 3$ \\
\hline & $\%$ change & -7 & & -1 & & -7 & & +6 & & -13 & \\
\hline
\end{tabular}

$K_{\mathrm{s}}$, rate of muscle protein synthesis; $K_{\mathrm{RNA}}$, rate of muscle protein synthesis per unit RNA; $K_{\mathrm{g}}$, rate of muscle protein growth; $K_{\mathrm{d}}$, rate of muscle protein degradation; BL (180 g casein $/ \mathrm{kg}$ diet group), baseline animals killed at the start of the dietary period; AC ( $180 \mathrm{~g}$ casein $/ \mathrm{kg}$ diet group), age controls killed at the end of the dietary period, at the same time as experimental diet groups.

$\dagger \%$ change values were calculated from the $\mathrm{AC} 180 \mathrm{~g}$ casein $/ \mathrm{kg}$ diet group.

Significantly different from AC $180 \mathrm{~g}$ casein $/ \mathrm{kg}$ diet group: ${ }^{*} P<0.05$.

significant. In the protein-free group in Expt M1 the $K_{\mathrm{RNA}}$ was markedly reduced by $44 \%$.

The changes in RNA concentration are less equivocal. In every case where protein synthesis was depressed, the RNA:protein ratio was significantly reduced and this accounted for the major part of the fall in protein synthesis.

\section{Partial correlation analysis}

When the interrelations between the variables measured in the present study were examined, it was clear that many of them were positively correlated with one another. To investigate the nature of these relations, the partial correlation coefficient was calculated between two variables, taking into account any joint interaction between these two variables and a third or fourth variable. A correlation matrix was established between pairs of variables, and these correlation coefficients were then used to calculate first-order and, in some cases, second-order partial correlation coefficients. In order to perform this analysis, pairs of variables must be linearly related with one another. In general, this was 


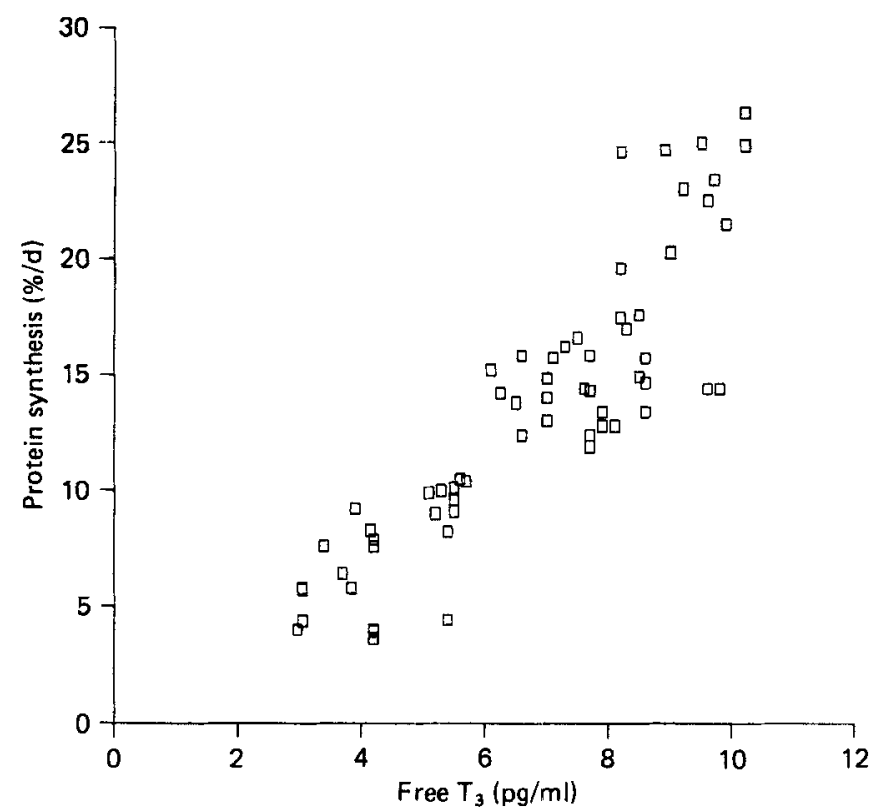

Fig. 3. Relation between the rate of protein synthesis in muscle $(\% / d)$ and plasma free $3,5,3^{\prime}-$ triiodothyronine $\left(\mathrm{T}_{3} ; \mathrm{pg} / \mathrm{ml}\right)$ in rats fed on diets of varying protein concentrations (including baseline animals) (for details, see p. 398).

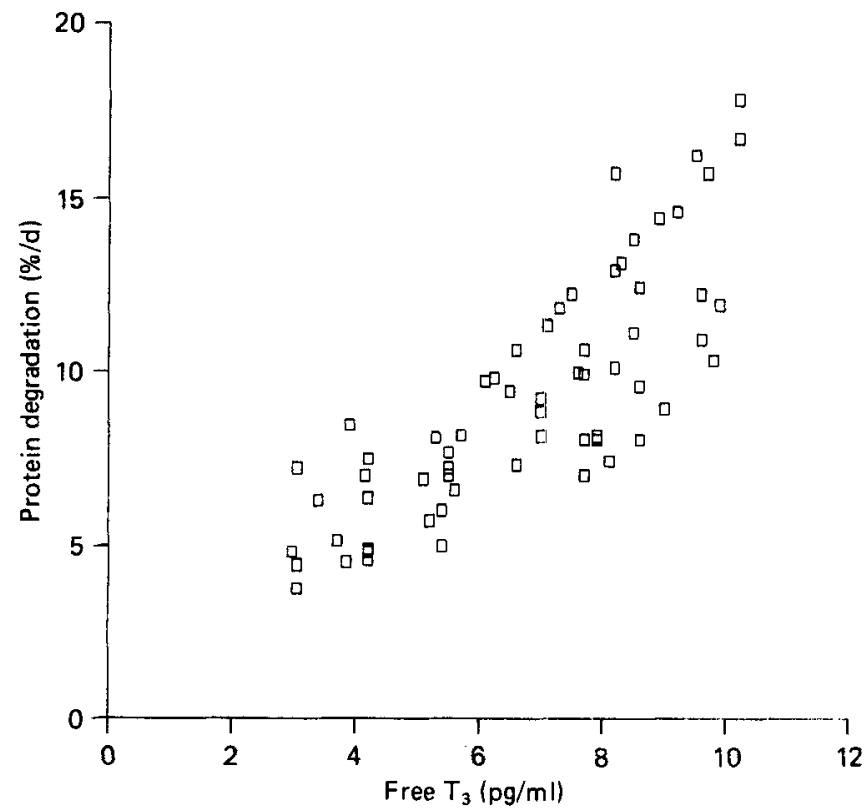

Fig. 4. Relation between the rate of protein degradation in muscle ( $\% / d)$ and plasma free $3,5,3^{\prime}$ triiodothyronine $\left(\mathrm{T}_{3} ; \mathrm{pg} / \mathrm{ml}\right)$ in rats fed on diets of varying protein concentrations (including baseline animals) (for details, see p. 398). 


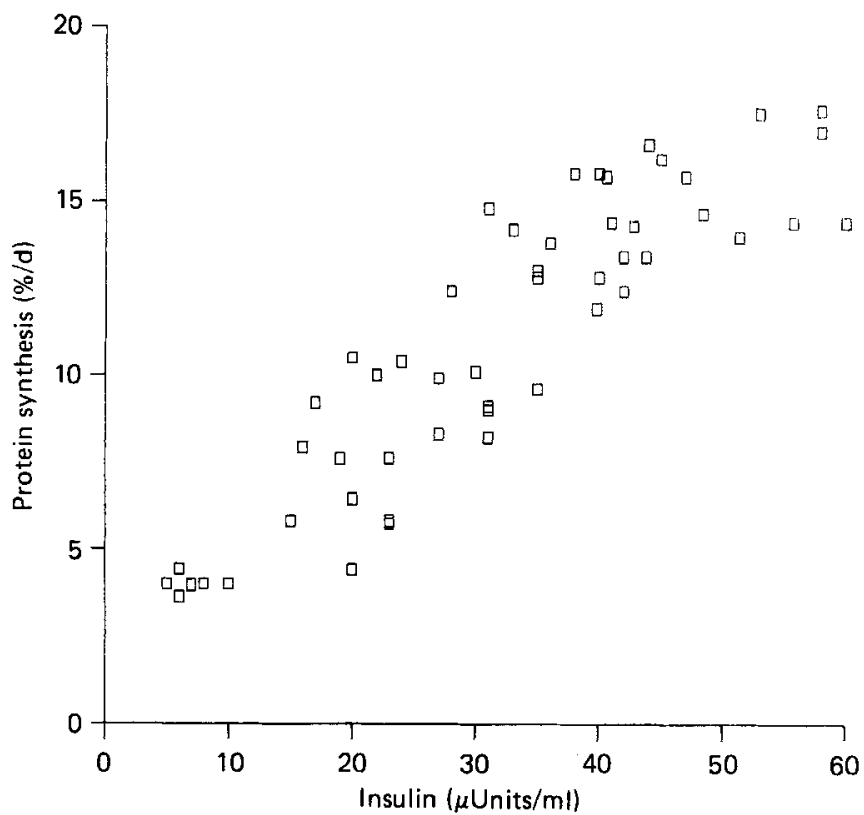

Fig. 5. Relation between the rate of protein synthesis $(\% / \mathrm{d})$ in muscle and plasma insulin $(\mu \mathrm{Units} / \mathrm{ml})$ in rats of similar ages fed on diets of varying protein concentrations (for details, see p. 398).

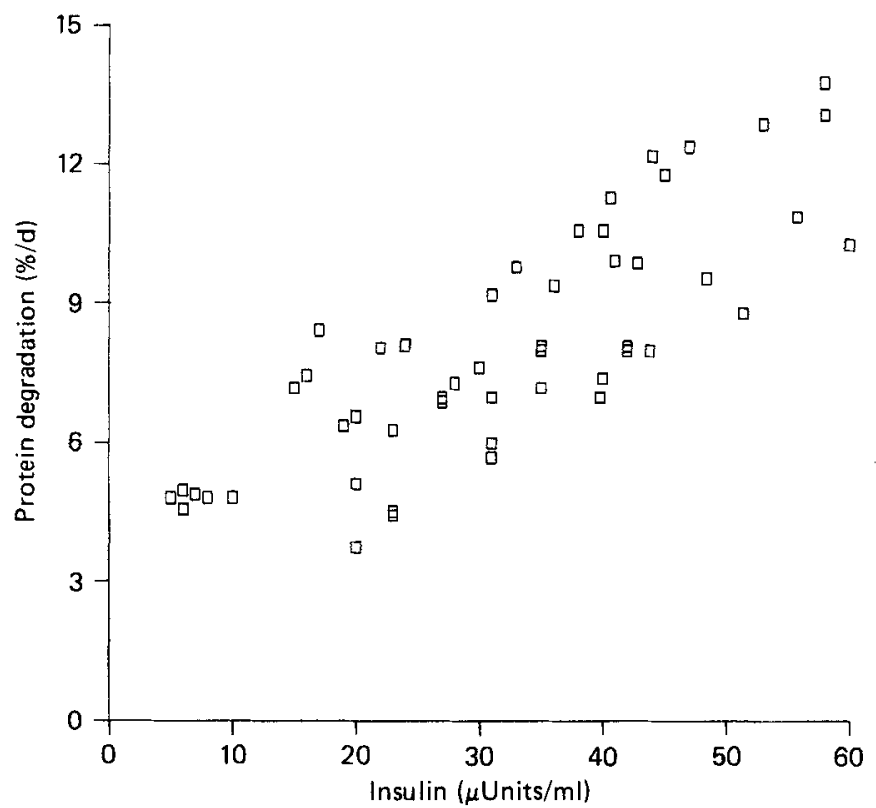

Fig. 6. Relation between the rate of protein degradation $(\% / d)$ in muscle and plasma insulin ( $\mu$ Units/ $\mathrm{ml}$ ) in rats of similar ages fed on diets of varying protein concentrations (for details, see p. 398). 


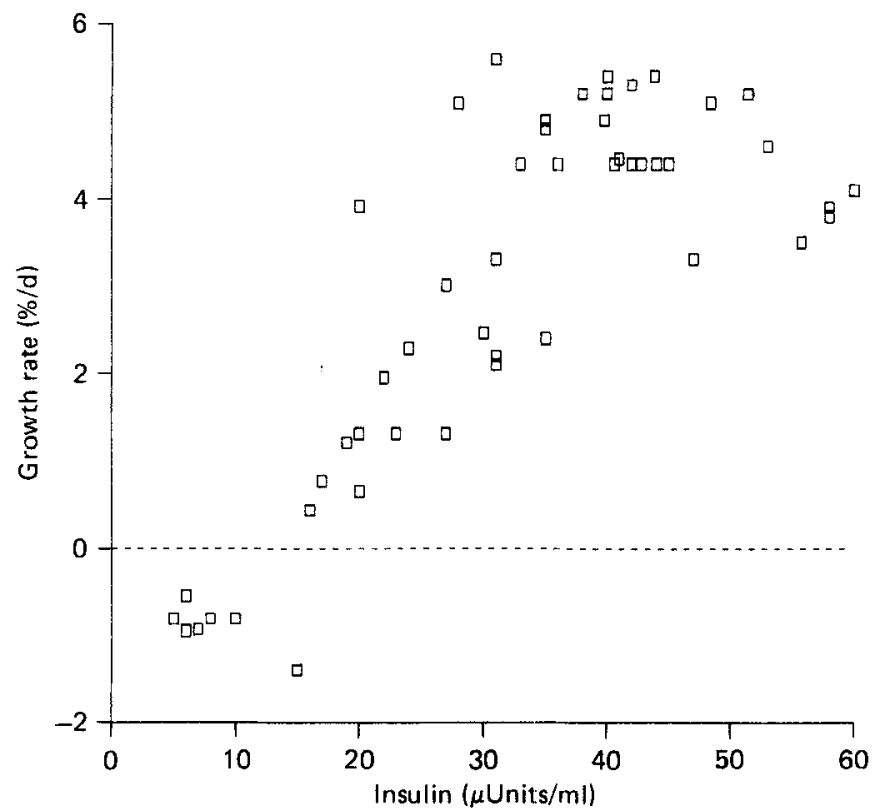

Fig. 7. Relation between the growth rate of muscle protein $(\% / \mathrm{d})$ and plasma insulin $(\mu$ Units $/ \mathrm{ml})$ in rats of similar ages fed on diets of varying protein concentrations (for details, see p. 398).

Table 6. Correlation analysis of plasma insulin, free 3,5,3'-triiodothyronine $\left(T_{3}\right)$, dietary protein $(P)$ and non-protein energy $(N P E)$ intake, and muscle growth and $P$ turnover

\begin{tabular}{|c|c|c|c|c|c|c|c|}
\hline \multicolumn{8}{|c|}{ Correlation coefficients $(r)$ ( $n$ 52) } \\
\hline & \multirow{2}{*}{$\begin{array}{c}\text { P intake } \\
0.327\end{array}$} & \multirow{2}{*}{$\begin{array}{c}\text { Insulin } \\
0.408\end{array}$} & \multirow{2}{*}{$\begin{array}{c}\text { Free } T_{3} \\
0.4097\end{array}$} & \multirow{2}{*}{$\begin{array}{c}K_{\mathrm{s}} \\
0.455\end{array}$} & \multirow{2}{*}{$\begin{array}{c}K_{\mathrm{d}} \\
0.280\end{array}$} & RNA:P & $K_{\mathrm{RNA}}$ \\
\hline NPE intake & & & & & & $0 \cdot 383$ & 0.321 \\
\hline$P$ intake & - & 0.858 & $0 \cdot 896$ & 0.816 & 0.662 & 0.785 & 0.445 \\
\hline Insulin & - & - & 0.877 & 0.897 & 0.818 & 0.677 & 0.677 \\
\hline Free $T_{3}$ & - & - & - & 0.873 & 0.772 & 0.778 & 0.491 \\
\hline \multicolumn{8}{|c|}{ Partial correlation coefficients $\left(r_{i j . k}\right)$} \\
\hline \multicolumn{5}{|c|}{ Variables } & \multirow{2}{*}{\multicolumn{3}{|c|}{$\begin{array}{c}\text { Statistical } \\
\text { significance: } P\end{array}$}} \\
\hline$i$ & \multicolumn{2}{|c|}{$j$} & \multicolumn{2}{|l|}{$k$} & & & \\
\hline$P$ intake & \multicolumn{2}{|c|}{ Insulin } & \multicolumn{2}{|c|}{ Free $T_{3}$} & & $0 \cdot 338$ & $<0.05$ \\
\hline$P$ intake & \multicolumn{2}{|c|}{ Free $T_{3}$} & \multicolumn{2}{|c|}{ Insulin } & & $0 \cdot 582$ & $<0.01$ \\
\hline$P$ intake & \multicolumn{2}{|c|}{ RNA:P } & \multicolumn{2}{|c|}{$\mathrm{T}_{3}$ (insulin) } & & $0 \cdot 341$ & $<0.05$ \\
\hline$P$ intake & \multicolumn{2}{|c|}{$K_{\mathrm{d}}$} & \multicolumn{2}{|c|}{$T_{3}^{3}$ (insulin) } & & -0.313 & $<0.05$ \\
\hline Insulin & \multicolumn{2}{|c|}{ Free $T_{3}$} & \multicolumn{2}{|c|}{$\mathrm{P}$} & & 0.475 & $<0.01$ \\
\hline Insulin & \multicolumn{2}{|c|}{$K_{\mathrm{s}}$} & \multicolumn{2}{|c|}{$\mathrm{P}\left(\mathrm{T}_{3}\right)$} & & 0.578 & $<0.01$ \\
\hline Insulin & \multicolumn{2}{|c|}{$K_{\mathrm{BNA}}$} & \multicolumn{2}{|c|}{$\mathrm{P}\left(\mathrm{T}_{3}\right)$} & & 0.619 & $<0.01$ \\
\hline Insulin & \multicolumn{2}{|c|}{$K_{\mathrm{d}}$} & \multicolumn{2}{|c|}{$\mathrm{P}\left(\mathrm{T}_{3}\right)$} & & 0.530 & $<0.01$ \\
\hline Free $T_{3}$ & \multicolumn{2}{|c|}{$K_{\mathrm{s}}$} & & (P) & & $0 \cdot 361$ & $<0.01$ \\
\hline Free $T_{3}$ & & $: P$ & & (P) & & $0 \cdot 367$ & $<0.01$ \\
\hline Free $T_{3}$ & & & $\mathrm{P}$ & & & $0 \cdot 342$ & $<0.05$ \\
\hline
\end{tabular}

$K_{\mathrm{s}}$, rate of muscle protein synthesis; $K_{\mathrm{d}}$, rate of muscle protein degradation; $K_{\mathrm{RNA}}$, rate of muscle protein synthesis per unit RNA. 


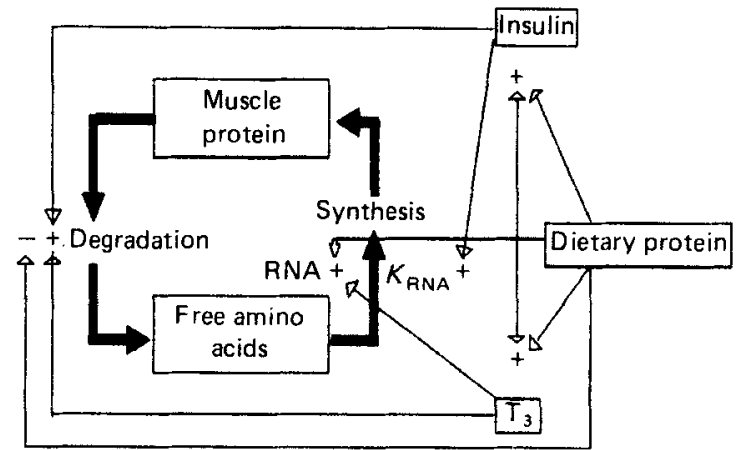

Fig. 8. Schematic representation of the apparent relation between diet, plasma insulin and free $3.5 .3^{\prime}$ triiodothyronine $\left(\mathrm{T}_{3}\right)$, and muscle protein turnover as indicated by partial correlation analysis (for details, see p. 406).

the case for most pairs as shown for free $T_{3}$ and muscle protein synthesis (Fig. 3) and degradation (Fig. 4), and insulin and muscle protein synthesis (Fig. 5) and degradation (Fig. 6). However, comparison of the growth rate with either plasma insulin (Fig. 7) or plasma free $T_{3}$, indicated a non-linear relation with a plateau of growth rate at high hormone concentrations. For this reason it was decided to exclude the growth rate from the partial correlation analysis, concentrating on the separate evaluation of the regulation of protein synthesis and degradation.

We were also concerned with the relation between the $K_{\mathrm{RNA}}$ and insulin. As would be expected from the results in Table 5 showing that the changes in the $K_{\mathrm{RNA}}$ and insulin were most apparent in the severely malnourished animals (the animals fed on the protein-free diet and the $45 \mathrm{~g}$ casein $/ \mathrm{kg}$ diet in Expt M1) the insulin- $K_{\mathrm{RNA}}$ relation was most marked at the lower end of the insulin range. Correlation coefficients were 0.871 ( $n 13)$ for insulin values $<20 \mu$ Units $/ \mathrm{ml}$ and $0.38(n 39)$ for values $>20 \mu$ Units $/ \mathrm{ml}$. This is consistent with previous information (Millward et al. 1983), indicating that insulin's action on the translational phase of protein synthesis may well be more apparent at the lower end of its physiological range. However, since each of these correlation coefficients was significant $(P<0.01)$ and since partial correlation analysis of the values separated into low- and highinsulin groups confirmed a significant relation between insulin and the $K_{\mathrm{RNA}}$ at high as well as low insulin concentrations, it was concluded that this pair of variables could be included in the analysis.

The matrix of selected correlation coefficients and the partial correlation coefficients which were found to be significant are shown in Table 6. It is clear that protein was the main dietary influence with no statistically identifiable influences of dietary non-protein energy. Dietary protein was independently positively correlated with insulin $(P<0.05)$ and free $\mathrm{T}_{3}$ levels $(P<0.01)$, as well as with muscle RNA concentrations $(P<0.05)$, and negatively correlated with proteolysis $(P<0.05)$. Insulin and free $\mathrm{T}_{3}$ were correlated with each other independently from any influence of dietary protein $(P<0.01)$ and both hormones were independently positively correlated with protein synthesis $(P<0.01)$, insulin influencing the $K_{\mathrm{RNA}}(P<0.01)$ and free $\mathrm{T}_{3}$ influencing muscle RNA concentration $(P<0.01)$. Finally each hormone was also positively correlated with the rate of proteolysis. These relations are represented schematically in Fig. 8. 


\section{DISCUSSION}

\section{Growth responses to protein deficiency}

The variable responses to the low-protein diets reported here are not entirely unexpected given the wide range of responses published by various workers, albeit as separate reports. Some report maintained or elevated intakes (Miller \& Payne, 1962; Tulp et al. 1979; Gurr et al. 1980; Rothwell et al. 1982; Lunn \& Austin, 1983; Swick \& Gribskov, 1983; Laurent et al. 1984) whilst others report decreased intakes (McCracken \& McAllister, 1984; Harri \& Brockway, 1985; Sawaya \& Lunn, 1985). Although various factors (e.g. age, environmental temperature and genetic background) have been shown to influence food intake, we were unable to identify any responsible factor. The change in the response to the $45 \mathrm{~g}$ casein $/ \mathrm{kg}$ diet (from Expt M2 to Expt M3) was evident after a change in the animal suppliers, and intrastrain differences in food intake responses to 'cafeteria' diets have previously been reported (Rothwell \& Stock, 1980). However, this could not explain our results since the animals from both sources exhibited a similar response to the $80 \mathrm{~g}$ casein/ $\mathrm{kg}$ diet (Expts M2, M3 and M4), whereas separate groups from the same supplier (Expts M1 and M2) showed different responses.

The observation of near normal growth (Expts M2 and M4) in rats of this age fed on a marginally-low-protein diet is, as far as we are aware, unique. Even when hyperphagia has been reported, growth restriction of the magnitude seen in Expt M1 is the usual response, and as we (Coyer et al. 1987) and others have shown (Tulp et al. 1979), this can be associated with an increased metabolic rate and decreased efficiency of energy deposition. However, in these current experiments measurements of the metabolic rate (see Jepson, 1986) indicated that in no case was there an increase, at least in the daytime measurements.

The growth rates of rats fed on marginally-protein-deficient diets will ultimately be limited by the extent to which food intake can be increased to provide sufficient protein. Our results indicate that, at least for rats of the ages we used, a hyperphagic response to an $80 \mathrm{~g}$ casein $/ \mathrm{kg}$ diet can provide enough dietary protein to allow near-normal rates of muscle growth. It must be assumed that the efficiency of protein utilization was increased compared with the control diet. Without an increase in the dietary intake (Expt M1), the protein intake is insufficient to allow control rates of deposition even with maximum efficiency of utilization. For the $45 \mathrm{~g}$ casein $/ \mathrm{kg}$ diet a much greater increase in intake would be required to provide sufficient protein for normal growth, so that the depressed growth rate with the marked hyperphagia (Expt M4) and the near total growth suppression with the reduced food intake (Expt MI) were not surprising.

\section{The regulatory influence of dietary protein}

The ability to make most use of available dietary protein for muscle growth requires a combination of rates of protein synthesis and degradation which give optimal net protein synthesis. This requires an appropriate regulatory response to the dietary constituents. The statistical relations between diet, the hormonal responses and muscle growth and protein turnover as revealed by partial correlation analysis help to identify physiologically important regulatory mechanisms. However, since any such relations could be indirect, reflecting other regulatory factors linked to those measured, it is necessary to consider them in the light of external evidence.

Protein, rather than non-protein energy, was identified as the main dietary influence in these studies, influencing muscle protein turnover independently of insulin or free $T_{3}$. The apparent stimulatory effect of dietary protein on muscle RNA could be direct, although the evidence that amino acids stimulate muscle ribosome levels is sparse. Recently glutamine concentrations in muscle have been shown to have a direct regulatory influence on muscle 
protein synthesis at the translational level (MacLennan et al. 1987); in addition we have reported a significant positive correlation between concentrations of muscle glutamine and RNA (Jepson et al. 1988), although it is not known whether the latter is a direct relation. In the present case the relation could well reflect the influence of hormonal factors not studied. Insulin-like growth factor-1 (IGF-1), for example, is known to be sensitive to dietary protein (Prewett et al. 1982; Yahya et al. 1986) and has been shown to exert the major influence on muscle-satellite-cell proliferation in culture (Dodson et al. 1985). Since DNA synthesis is rate-limiting for RNA synthesis in normal muscle growth (Millward, 1980), this action of IGF-1 could account for the dietary protein-muscle RNA correlation.

The lack of any apparent stimulatory effect of dietary protein on the $K_{\mathrm{RNA}}$ is consistent with our previous studies, in which we were unable to influence the $K_{\mathrm{RNA}}$ in muscle of diabetic rats by infusions of amino acids and glucose without insulin (Odedra et al. 1982). On the other hand, according to Preedy \& Garlick (1986), the reported influence of dietary amino acids acts as an additional stimulus (to insulin) on muscle protein synthesis. Clearly this aspect of dietary protein's role requires further investigation.

As far as the apparent inhibitory effect of dietary protein on protein degradation is concerned, this is consistent with the reported suppression of proteolysis by amino acids in incubated muscle which, according to Mitch \& Clark (1984), involves the specific influence of the keto acid of leucine (4-methyl 2-oxopentanoate).

Dietary protein also appears to act by regulating the hormones insulin and $\mathrm{T}_{3}$, each of which have been implicated in the regulation of muscle protein synthesis and degradation (Flaim et al. 1978; Goldberg et al. 1980; Jefferson, 1980; Tischler, 1981; Millward, 1985; Millward et al. 1985). Amino acids are known to be an important stimulus for insulin secretion (Fajans \& Floyd, 1972), together with glucose, gastrointestinal hormones, and adrenergic and cholinergic innervation (Berthoud, 1984). In addition Okajima \& Ui (1978) have shown that thyroid hormone status influences adrenergic responsiveness of insulin secretion. As to any direct influence of dietary protein on $\mathrm{T}_{3}$, this is not well documented, but could also reflect neural responses to protein intake acting on the monodeiodinase since it is known that at least one monodeiodinase (in brown adipose tissue) is under adrenergic control (Silva \& Larsen, 1983). The apparent relation between insulin and $\mathrm{T}_{3}$ is certainly consistent with the known role of insulin in the regulation of the hepatic monodeiodination of thyroxine $\left(\mathrm{T}_{4}\right)$ (Sato \& Robbins, 1981; Gavin \& Moeller, 1983). It is not known whether insulin could influence $T_{3}$ binding and hence free $T_{3}$ levels.

\section{Role of insulin}

Insulin is known to stimulate the translational phase of muscle protein synthesis (Jefferson, 1980 ) and in our studies appeared to stimulate the $K_{\mathrm{RNA}}$ throughout its physiological range. This reduced protein synthesis through reduced translation is consistent with many earlier studies on the response of muscle to very severe protein deficiency and starvation, which showed a depressed $K_{\mathrm{RNA}}$ (Millward et al. 1975; Garlick et al. 1975; Waterlow et al. 1978). However, recent studies with marginally-low-protein diets show the $K_{\mathrm{RNA}}$ to be well maintained (Emery et al. 1983). Our present results generally confirm this, since significant reductions in the $K_{\mathrm{RNA}}$ occurred only in two low-protein groups. In refed fasted rats the insulin sensitivity of muscle protein synthesis is only apparent at low insulin concentrations (Millward et al. 1983) and concentrations as low as $10 \mu \mathrm{Units} / \mathrm{ml}$ are sufficient to allow modest increases in the $K_{\mathrm{RNA}}$ with feeding in zinc-deficient rats (Giugliano \& Millward, 1986). In the present study simple regression of $K_{\mathrm{RNA}}$ on insulin shows that although significant correlation is apparent over the entire insulin range, the slope is greater in the low insulin range by a factor of 3 .

The apparent stimulation of proteolysis by insulin is in marked contrast to its widely- 
assumed role of inhibiting proteolysis (Goldberg, 1979). However, in contrast to these studies of the response to high doses of insulin in incubated unstretched muscles in which proteolysis is markedly elevated, more recent studies show that in muscles incubated under constant tension with proteolysis maintained at in vivo rates, physiological levels of insulin stimulate both protein synthesis and proteolysis whereas the addition of pharmacological doses of insulin stimulated only protein synthesis (Palmer et al. 1985; Palmer, 1987). Thus it is possible that these parallel, insulin-mediated increases in protein synthesis and proteolysis, which we have termed 'anabolic proteolysis' (Millward et al. 1985), may well be physiologically distinct from the 'catabolic proteolysis' observed in terminal starvation when the increase in proteolysis is accompanied by a decrease in protein synthesis (Millward \& Waterlow, 1978).

\section{Role of $T_{3}$}

The apparent stimulation of muscle RNA concentrations by free $T_{3}$ is consistent with previous reports showing a loss of muscle RNA after thyroidectomy (Flaim et al. 1978), occurring before any fall in food intake or insulin (Brown et al. 1981) and showing the restoration of muscle RNA levels in thyroidectomized rats treated with $\mathrm{T}_{4}$ (Flaim et al. 1978) or $T_{3}$ (Brown \& Millward, 1983). Treatment of diabetic rats with $T_{3}$ reversed the loss of muscle and liver RNA caused by the diabetes (Brown et al. 1983). Since $T_{3}$ has been shown to have a direct effect on the maturation phase of cartilage growth in culture, separate from IGF-1 (Burch \& Van Wyk, 1987), it is possible that its action on muscle is also direct.

The apparent stimulation of proteolysis by free $T_{3}$ is consistent with several previous experimental studies (Burman et al. 1979; Millward et al. 1980; Brown et al. 1981; Brown \& Millward, 1983), and has been proposed to reflect stimulation of lysosomal proteinases (DeMartino \& Goldberg, 1978), as well as the $\mathrm{Ca}^{2+}$-activated neutral proteinase (Zeman et al. 1986). However, the significance of physiological changes in $T_{3}$ protein deficiency in the rat has been confusing and difficult to interpret (e.g. Burini et al. 1981) because of the differential changes in free and total $\mathrm{T}_{3}$ levels in protein deficiency in the rat, described here and previously (Smallridge et al. 1982; Young et al. 1982; Cox et al. 1984).

It has previously been suggested that the fall in the rate of proteolysis is a specific thyroid hormone-mediated adaptation minimizing growth failure induced by impaired protein synthesis (Millward et al. 1985). Since in our studies we cannot distinguish between $T_{3}$ and insulin as regulatory influences on proteolysis, description of a specific $\mathrm{T}_{3}$-mediated adaptation in protein deficiency is questionable. In any case such a definition ignores the fact that since $T_{3}$ stimulates protein synthesis as well as proteolysis, reduced $T_{3}$ could be partly responsible for the impaired protein synthesis and the reduced growth with protein deficiency. However when changes in thyroid hormone levels occur without changes in other anabolic hormones, as in hypophysectomized rats treated with $\mathrm{T}_{3}$ (Brown et al. 1981), there are parallel changes in muscle protein synthesis and degradation but little growth. In cartilage growing in culture, in the absence of IGF- $1, \mathrm{~T}_{3}$ mediates structural reorganization associated with maturation but permits only limited increase in size (Burch \& Van Wyk, 1987). The current findings are consistent with a similar role for $T_{3}$ in muscle involving mediation of increased turnover during growth-related remodelling, acting in concert with other growth factors which induce the net increase in protein synthesis.

Some authors report reduced growth with protein deficiency which they attribute to a hyperthyroid state (Lunn \& Austin, 1983; Carter et al. 1984; Sawaya \& Lunn, 1985) and imply that the thyroid-mediated strategies adopted to deal with any excess energy intake are crucial to the ability to maintain growth on low-protein diets. This is not consistent with our findings showing that thyroid hormone status reflects dietary protein rather than 
energy intake. In any case, in a hypermetabolic state, changes in other hormones and regulatory factors (e.g. sympathetic nervous system activity, Landsberg \& Young, 1983) may alter the relation between $T_{3}$ and muscle-protein turnover. Thyroidectomized rats treated with a relatively high dose of thyroid hormones exhibited either plateauing of muscle protein synthesis (Brown \& Millward, 1983) or inhibition (Flaim et al. 1978); and clinical hyperthyroidism is known to be catabolic, indicating that some factor either alters or overrides the relation between thyroid hormone status and muscle protein synthesis and degradation observed here. This suggests that it was the absence of a hyperthyroid response to the hyperphagia in the groups fed on the marginally-low-protein diets that facilitated the near-normal growth by preventing a disproportionate increase in degradation.

This work was generously supported by the Medical Research Council, the Wellcome Trust and the Nestlé Nutrition Programme.

\section{REFERENCES}

Bernhardt, F. W. \& Tomarelli, R. M. (1966). Journal of Nutrition 89, 495-500.

Berthoud, H. R. (1984). Metabolism 33, 18-25.

Brown, J. G., Bates, P. C., Holliday, M. A. \& Millward, D. J. (1981). Biochemical Journal 194, 771-782.

Brown, J. G. \& Millward, D. J. (1983). Biochimica et Biophysica Acta 757, 182-190.

Brown, J. G., van Bueren, J. \& Millward, D. J. (1983). Biochemical Journal 214, 637-640.

Burch, W. M. \& Van Wyk, J. J. (1987). American Journal of Physiology 252, E176-E182.

Burini, R., Santidrian, S., Moreyra, M., Brown, P., Munro, H. N. \& Young, V. R. (1981). Metabolism 30, 679687.

Burman, K. D., Wartofsky, L., Dinterman, R. E., Kesler, P. \& Wannemacher, R. W. (1979). Metabolism 28, 805-813.

Carter, W. J., van der Weijden Benjamin, W. S. \& Faas, F. H. (1984). Biochemical Journal 217, 471-476.

Cox, M. D., Dalal, S. S., Heard, C. R. C. \& Millward, D. J. (1984). Journal of Nutrition 114, 1609-1616.

Coyer, P., Rivers, J. P. W. \& Millward, D. J. (1987). British Journal of Nutrition 58, 73-85.

DeMartino, G. N. \& Goldberg, A. L. (1978). Proceedings of the National Academy of Sciences, USA 75, 13691373.

Dodson, M. V., Allen, R. E. \& Hossner, K. L. (1985). Endocrinology 117, 2357.

Edozien, J. C., Niehaus, N., Mar, M.-H., Makoui, T. \& Switzer, B. R. (1978). Journal of Nutrition 108, 1767 1776.

Emery, P. W., Rothwell, N. J. \& Stock, M. J. (1983). Bioscience Reports 3, 569-575.

Fajans, S. S. \& Floyd, J. C. Jr (1972). In Handbook of Physiology, sect. 7, vol. 1, pp. $473-493$ [D. F. Steiner and N. Freinkel, editors]. Washington, DC: American Physiological Society.

Flaim, K. E., Li, J. B. \& Jefferson, L. S. (1978). American Journal of Physiology 235, E231-E236.

Garlick, P. J, McNurlan, M. A. \& Preedy, V. R. (1980). Biochemical Journal 192, 719 723.

Garlick, P. J., Millward, D. J., James, W.P. T. \& Waterlow, J. C. (1975). Biochimica et Biophysica Acta 414, 71-84.

Gavin, L. A. \& Moeller, M. (1983). Metabolism 32, 543-551.

Giugliano, R. \& Millward, D. J. (1986). British Journal of Nutrition 57, 139-155.

Goldberg, A. L. (1979). Diabetes 28, 18-24.

Goldberg, A. L., Tischler, M., DeMartino, G. \& Griffin, G. (1980). Federation Proceedings 39, 31-36.

Gurr, M. I., Mawson, R., Rothwell, N. J. \& Stock, M. J. (1980). Journal of Nutrition 110, $532-542$.

Harri, M. \& Brockway, J. M. (1985). British Journal of Nutrition 53, 363-372.

Jefferson, L. S. (1980). Diabetes 29, 487-496.

Jepson, M. M. (1986). Mechanisms of the response of skeletal muscle and liver protein metabolism to dietary protein and endotoxaemia in young rats. PhD Thesis, University of London.

Jepson, M. M., Pell, J. M., Bates, P. C., Broadbent, P. \& Millward, D. J. (1988). American Journal of Physiology (In the Press).

Jepson, M. M., Pell, J., Bates, P. \& Millward, D. J. (1986). Biochemical Journal 235, 329-336.

Landsberg, L. \& Young, J. B. (1983). American Journal of Clinical Nutrition 38, 1018-1024.

Laurent, B. C., Moldawer, L. L., Young, V. R., Bistrian, B. R. \& Blackburn, G. L. (1984). American Journal of Physiology 246, E444-E451.

Lunn, P. G. \& Austin, S. (1983). Journal of Nutrition 113, 1791-1802.

McCracken, K. J. \& McAllister, A. (1984). British Journal of Nutrition 51, 225-234.

MacLennan, P. A., Brown, R. A. \& Rennie, M. J. (1987). FEBS Letters 215, 187-191.

Miller, D. S. \& Payne, P. R. (1962). Journal of Nutrition 78, 255-262. 
Miller, S. A. (1969). In Mammalian Protein Metabolism, pp. 183-227 [H. N. Munro, editor]. New York and London: Academic Press.

Millward, D. J. (1980). In Degradative Processes in Heart and Skeletal Muscle, pp. 161-199 [K. Wildenthal, editor]. Amsterdam: North Holland.

Millward, D. J. (1985). In Substrate and Energy Metabolism in Man, pp. 135-144 [D. Halliday and J. S. Garrow, editors]. London and Paris: John Libbey.

Millward, D. J., Bates, P. C., Brown, J. G., Cox, M. C., Giugliano, R., Jepson, M. \& Pell, J. (1985). In Intracellular Protein Catabolism, pp. 531-542 [E. A. Khairallah, J. S. Bond and J. W. C. Bird, editors]. New York: Alan Liss.

Millward, D. J., Garlick, P. J., Nnanyelugo, D. O. \& Waterlow, J. C. (1976). Biochemical Journal 156, 185 188.

Millward, D. J., Garlick, P. J., Stewart, R. J. C., Nnanyelugo, D. O. \& Waterlow, J. C. (1975). Biochemical Journal 150, 235-243.

Millward, D. J., Nnanyelugo, D. O. \& Garlick, P. J. (1974). British Journal of Nutrition 32, 127-142.

Millward, D. J., Odedra, B. \& Bates, P. C. (1983). Biochemical Journal 216, 583-587.

Millward, D. J. \& Waterlow, J. C. (1978). Federation Proceedings 37, 2283-2290.

Mitch, W. E. \& Clark, A. S. (1984). Biochemical Journal 222, 579-586.

Odedra, B., Bates, P. C. \& Millward, D. J. (1983). Biochemical Journal 214, 617-627.

Odedra, B., Dalal, S. S. \& Millward, D. J. (1982). Biochemical Journal 202, 363-368.

Okajima, F. \& Ui, M. (1978). American Journal of Physiology 234, E106-E111.

Palmer, R. M. (1987). The role of prostaglandins in the hormonal control of protein turnover. PhD Thesis, University of Aberdeen.

Palmer, R. M., Bain, P. A. \& Reeds, P. J. (1985). Biochemical Journal 230, 117-123.

Preedy, V. R. \& Garlick, P. J. (1986). Bioscience Reports 2, 177-183.

Prewett, T. E. A., D'Ercole, A. J., Switzer, B. R. \& Van Wyk, J. J. (1982). Journal of Nutrition 112, 144-150.

Rothwell, N. J. \& Stock, M. J. (1980). Proceedings of the Nutrition Society 39, 20A.

Rothwell, N. J., Stock, M. J. \& Tyzbir, R. S. (1982). Journal of Nutrition 112, 1663-1672.

Rothwell, N. J., Stock, M. J. \& Tyzbir, R. S. (1983). Metabolism 32, 257-261.

Sato, K. \& Robbins, J. (1981). Journal of Clinical Investigation 68, 475-483.

Sawaya, A. L. \& Lunn, P. G. (1985). British Journal of Nutrition 53, 175-181.

Silva, J. E. \& Larsen, P. R. (1983). Nature 305, 712-713.

Smallridge, R. C., Glass, A. R., Wartofsky, L., Latham, K. R. \& Burman, K. D. (1982). Metabolism 31, 538542.

Snedecor, G. W. \& Cochran, W. G. (1967). In Statistical Methods, 6th ed., pp. 381-418. Ames, Iowa: Iowa State University Press.

Swick, R. W. \& Gribskov, C. L. (1983). Journal of Nutrition 113, 2289-2294.

Tischler, M. E. (1981). Life Sciences 28, 2569-2576.

Tulp, O. L., Krupp, P. P., Danforth, E. Jr \& Horton, E. S. (1979). Journal of Nutrition 109, 1321-1322.

Waterlow, J. C., Garlick, P. J. \& Millward, D. J. (1978). Protein Turnover in Mammalian Tissues and the Whole Body. Amsterdam: Elsevier/North-Holland Biomedical Press.

Yahya, Z. A. H., Bates, P. C., Dalal, S. S., Morell, D., Holder, A. T., Taylor, A. \& Millward, D. J. (1986). Proceedings of the Nutrition Society 45, 107A.

Young, R. A., Braverman, L. E. \& Rajatanavin, R. (1982). Endocrinology 110, 1607-1612.

Zeman, R. J., Bernstein, P. L., Ludemann, R. \& Etlinger, J. D. (1986). Biochemical Journal 240, $269-272$. 